\title{
The Effects of Physical, Emotional, and Cognitive Demands on Academic Leaders' Performance in Malaysian Research Universities
}

\author{
Mayadah Graizi \\ University of Malaya, Kuala Lumpur, Malaysia \\ https://orcid.org/0000-0002-8298-5637 \\ Kenny S. L. Cheah \\ University of Malaya, Kuala Lumpur, Malaysia \\ https://orcid.org/0000-0001-9881-582X \\ Kazi Enamul Hoque \\ University of Malaya, Kuala Lumpur, Malaysia \\ https://orcid.org/0000-0002-8152-9250
}

\begin{abstract}
This study attempted to investigate the possible impact of physical, emotional, and cognitive job demands on burnout among Malaysian academic leaders at Research Universities (RU). Another objective of the study was to study the direct and mediating role of burnout on the job performance of the target population. Through a quantitative study and by using a five-Likert point, 250 academic leaders in Malaysian Research Universities (MRUs) were surveyed. The obtained primary data were subject to quantitative analysis through outer loading of the items using Smart PLS software. The exploratory and confirmatory tests applied to the primary data earlier to the inferential tests started with testing the direct hypotheses structured followed by the indirect effect. Findings indicated that based on the model extracted and the loaded factors, it was found that cognitive, emotional, and physical demands have a significant impact on burnout. Burnout also showed a significant effect on in-role and extra-role performance of the academic leaders and an indirect effect of burnout between job demands and job performance was observed. As an implication, this study can have pedagogical implications for educational policymakers, education syllabus designers, and academic leaders. Assessing the interaction role of gender type suggests further research, which benefit the policymakers in diversifying the job demand for each type.
\end{abstract}

Keywords: job demands; job performance; burnout; academic leadership; research university 


\section{Introduction}

An emerging concept among academicians is academic leadership (Lorello et al., 2020). Academic leadership is an interest among scholars at Research Universities (RU) who seek excellence in research and education (Burkinshaw \& White, 2019). Rathmell et al. (2019) explain that academic leadership is the ability to use various skills to overcome the challenges encountered by academicians. They also state that academic leadership in one generation affects the leadership among the next generation of academicians.

Burkinshaw and White (2019) take a gender-based view and explain that males and females have not been granted equal opportunities to take an academic lead. Qamar et al. (2019) believe that non-academic aspects of work affect academic leadership. They refer to these variables as external variables. However, the focus of most scholars has been on the effects of academic leadership on academic performance (e.g., Qamar et al., 2019; Sinniah et al., 2018; Sung et al., 2017).

In line with many western societies, academic leadership has also been investigated in Malaysia (Arbae et al., 2019; Ismail \& Noor, 2016; Omar, 2018; Rahman et al., 2019). Although these studies mostly look into the professional role of academic leaders, they mostly neglect the possible factors that can affect academic leadership (Zarb, 2016). The most common variables investigated in these studies are unproportioned job demands (Bakker \& Demerouti, 2007), academic leaders' wellbeing (Bakker \& Demerouti, 2014), and performance (Saleem et al., 2017).

It seems that unproportioned job demand is one of the most common themes studied in Malaysia and in the global context. Bakker and Demerouti (2018) assert that every job demand has a cost for the employees. In case there is an imbalance between the cost and energy for the employees, they undergo job-related stress. Bakker and Demeroutil (2007) identify the main aspects of job demand as physical, emotional, and cognitive aspects. Also, and according to Ilies et al. (2015) and Nahrgang et al. (2011), while emotional and physical demands cause burnout, cognitive demands result in mental tiredness. Burnout (also known as strain) can eventually affect job efficacy among academic leaders (Friedman, 2000). This indicates that a serious look at the factors that result in burnout among academicians is required, as excessive physical and emotional demands decrease work efficacy among academicians (Bowen et al., 2016). However, research conducted in Malaysia has mostly focused on pedagogy, and less attention has been given to job demands (e.g., Rahman et al., 2019).

In terms of academic leaders' performance, most research has accorded focus to professional role and relationships rather than job demands and burnout (Arbae et al., 2019; Omar, 2018; Ismail \& Noor, 2016). The question left open is how burnout and job demands are associated among Malaysian academic leaders. While burnout can possibly affect performance (Al-Dubai et al., 2013), and decrease organizational commitment (Bte Marmaya et al., 2011), little attention has been given to it in the context of Malaysia. Needless to say that the job 
performance in educational contexts is as important as any other context. Williams and Anderson (1991), who provide a lateral taxonomy of job performance (in-role vs. extra-role), assert that in-role job performance (task performance) and extra-role performance (organizational citizenship behavior (OCB) or contextual performance) should be equally attended.

The educational sector in Malaysia is experiencing very swift changes, as the number of universities is increasing and the need for qualified staff is obvious (Yousefi \& Abdullah, 2019). Mustapha (2013) stated that little research has dealt with the academic leaders in RUs at the centre of such changes. In line with these swift changes, the knowledge-based economy within Malaysian higher education requires adroit academic leaders (Grapragasem et al., 2014). This indicates that maintaining an academic position is harder than before, and the educators are under stress to produce knowledge and show high levels of in-role and extra-role performance. Such difficulties are the result of unproportioned job demands which have not been solved yet.

There are scholastic pieces of evidence that indicate academicians' burnout should be subject to more research in the context of Malaysia. Not only is burnout one of the main influential factors on work performance in the educational sector (Al-Dubai et al., 2013), but also it can decrease organizational support (Bte Marmaya et al., 2011). On the other hand, burnout is the result of the stressors the Malaysian academicians encounter in higher education (Fullan $\&$ Scott, 2009). Yet, whether these stressors are emotional, cognitive, or physical is not fully known.

Khairuddin and Makhbul (2011) who point to the academic performance of the academic leaders assert that at Research Universities (RUs), academic performance is not studied satisfactorily. The consensus in the literature is that not only should the academic leadership problems in Malaysia be investigated, but also the factors affecting the academic leaders' performance should be investigated. These two main problems form the main intention to conduct this study.

According to the problems stated above, this study has two main objectives, namely, 1) To find out how various forms of job demand affect burnout; 2) To determine how burnout affects job performance. To have an accurate look at this issue, both direct and indirect impacts of burnout on job demand are studied. Also, job performance is viewed as in-role and extra-role performance of Malaysian academicians.

\section{Literature Review}

Various theories that discuss job demand consider three main aspects, i.e., physical, psychological, and social (organizational) for job demand (DeFrank \& Ivancevich, 1998; Schaufeli \& Bakker, 2004). Job demand, if assigned proportionately, can have positive effects; however, unproportionate job demands can have negative effects on the performance of the employees and the outcome of an organization. According to Bakker and Demerouti (2018), some 
variables also play a role in the relationship between job demand and job performance. Burnout and motivation are the most important variables. In simple terms, long working shifts and excessive work pressure can result in burnout or even depression and eventually affect the performance of the employees. These variables have been subject to scientific studies and a number of theoretical bases have emerged as a result of these studies.

\section{Theoretical Framework}

The main theory used in this study is that of Job Demand-Resource (JDR) theory. However, to justify the use of JDR theory, some of the relevant previous theories should be explained. One of the most significant theories is the Path-Goal theory. Yukl and Lepsinger (2006) explain that the Path-Goal theory is a leadership theory that sees the leaders' behaviour as the result of their satisfaction, motivation, and eventually, their performance. This theory associates the leaders' behaviour to their subordinate's abilities that compensate for deficiencies (Bakker \& Demerouti, 2014). Thus, the researchers should attempt to see how the contingency perspective to leadership is associated with conditions or situational variables that affect the relationship between leaders' behavior and effectiveness (Madonko \& April, 2020). The types of leaders' behaviour in Path-Goal theory, as stated by Muchinsky (2006), are directive, supportive, participative, and achievement-oriented. While directive behaviors tend to remove obstacles that cause frustrations, supportive behaviors lead to understanding subordinates' needs and increasing their wellbeing. Participative and achievement-oriented behaviors lead to investments in the ideas of subordinates, and encouraging a high performance, respectively (Muchinsky, 2006).

Raziq et al. (2018) divide the behavior in Goal-Path theory into three main categories. These categories centre on satisfaction and refer to immediate and future satisfaction, along with tools to satisfy subordinates' needs contingent with effective performance (House \& Dessler, 1974). The main tools are support and guidance in the work environment.

\subsection{Stress Theories}

The relationship between stress and job environment is a conditional-stimuli relationship (Jex et al., 1992). Jex et al. (1992) also assert that the stimulus for stress in the job environment can be any job-related demand that causes burnout. Thus, according to Kinman and Jones (2005), there should be a balance between job demands and personal abilities. This relationship is known as job-personal resources. Job-personal resources are the basis of many job stress theories, which have mature in different ways. One of the mostly used theories in this regard is that of the Job Demand-Resource model.

\subsection{The Job Demand-Resource Model (JDR)}

The job demand-resource (JDR) model is the theoretical basis of this study. This theory does not only centre on specific types of job conditions. In this theory, the job characteristics are broad (Bakker \& Demerouti, 2017). The theory is a globally-proven theory and has been used in many studies. According to Bakker 
and Demerouti (2014), it has been mainly used to describe employees' wellbeing (like burnout/strain, motivation, health, engagement, satisfaction, commitment) and performance (in-role and extra-role). Although the theoretical building block of JDR theory is based on certain assumptions, the theory asserts that the working conditions can introduce new variables in the analysis (Bakker \& Demerouti, 2007).

\subsection{Conceptual Framework}

The model below (Figure 1) shows the JDR theory based on the variables under investigation in the current study. As can be seen in the model, and based on the JDR model, three main categories of job demand, i.e., physical, emotional, and cognitive, are investigated as possible influencers of burnout. This possible impact may affect in-role and extra-role performance of the academic leaders which is also investigated based on this model. Finally, the mediating role of burnout is explored.

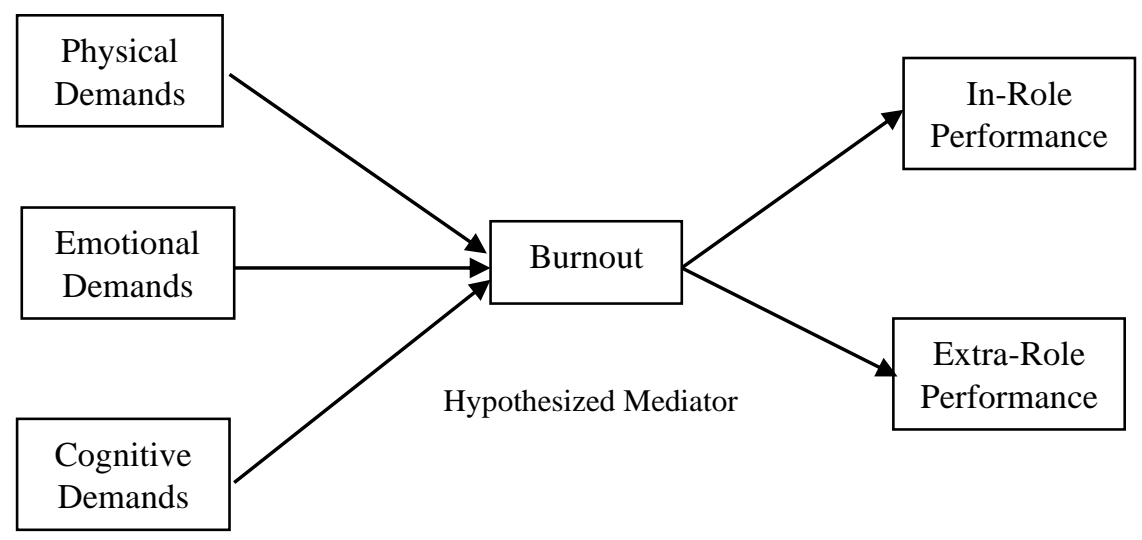

Figure 1: Academic leaders' performance in Malaysia research universities

\section{Previous Empirical Studies}

Some studies have been conducted on the relationship between job demands and job performance in Malaysia. Reviewing these studies brought the researchers to the conclusion that there is a certain need to study the impact of job demands on burnout and the direct and indirect impact of burnout on job performance, and these variables are not deeply investigated in the literature yet (Zysberg et al., 2017).

The correlations between occupational stress and job performance with a focus on emotional intelligence were investigated by Ismail et al. (2009). They studied 104 academicians at private universities in Malaysia and realized that occupational stress and job performance correlate. They also found out that emotional intelligence is a significant role player and mediates the relationship between these two variables. Watts and Rohertson (2011) also worked on

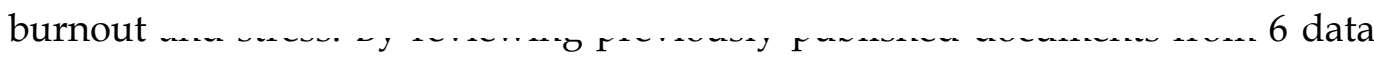
resources, they could conclude that burnout and teachers' stress in higher 
education are associated. Their content analysis also showed that gender has a predictive role and female staff are more subject to burnout.

Studies conducted in other parts of the world are mostly congruent with these results. For example, in the context of Austrialia, Winefield et al. (2003) saw a significant relationship between burnout and lack of job satisfaction. By surveying 9000 academicians in seventeen universities, they realized that the new generation of academicians is more subject to burnout compared to the older staff. They also found that self-report measures of psychological wellbeing were highly had associations with objective measures of university wellbeing. In another study in Spain, burnout was observed among school teachers in Spain. Prieto et al. (2008) realized that work overload could predict exhaustion and prediction. They found the results by studying 274 teachers at 23 different secondary schools.

In Pakistan, Saleem et al. (2017) realized that the type of leadership affects burnout. They reported that the principals' leadership styles and teachers' organizational commitment are highly correlated. Through looking at the indirect impact of emotional intelligence (EI) and perceived organizational support (POS), they reported that the principals prefer a democratic leadership style (EI and POS). Another significant finding in their study was that the leadership styles and organizational commitment are highly correlated.

The previous studies discussed within Table 1 lack the challenging cognitive demands at work (Meyer \& Hünefeld, 2018). Hence, the need to highlight the cognitive demand in academic work is rising. To fill this gap, this study identified cognitive demand as a latent factor as a determinant of burnout at academic work. The researcher reviewed more studies. The synopsis of these studies is presented in Table 1.

Table 1: Summary of the previous studies

\begin{tabular}{|c|c|c|c|c|c|}
\hline $\mathbf{N}$ & $\begin{array}{l}\text { Authors and } \\
\text { Date }\end{array}$ & Design & $\begin{array}{l}\text { Instrument } \\
\text { Type }\end{array}$ & $\begin{array}{l}\text { Participants and } \\
\text { Context }\end{array}$ & Result \\
\hline 1 & $\begin{array}{l}\text { Kasinathan, } \\
\text { and } \\
\text { Arokiasamy } \\
\text { (2019) }\end{array}$ & Quantitative & $\begin{array}{l}\text { Survey } \\
\text { Questionnaire }\end{array}$ & $\begin{array}{l}\text { Malaysian } \\
\text { Universities }\end{array}$ & $\begin{array}{l}\text { There are } \\
\text { interventions at } \\
\text { organizational } \\
\text { level to promote } \\
\text { well-being of } \\
\text { academicians. }\end{array}$ \\
\hline 2 & $\begin{array}{l}\text { Zysberg et al. } \\
\text { (2017) }\end{array}$ & Quantitative & $\begin{array}{l}\text { Likert scale } \\
\text { questionnaire }\end{array}$ & $\begin{array}{l}1230 \text { daycare } \\
\text { educators and } \\
2209 \text { school } \\
\text { teachers }\end{array}$ & $\begin{array}{l}\text { Burnout has } \\
\text { associations with } \\
\text { personality and } \\
\text { emotional } \\
\text { intelligence. In this } \\
\text { way, stress affects } \\
\text { burnout }\end{array}$ \\
\hline 3 & $\begin{array}{l}\text { Mérida-López, } \\
\text { and Extremera } \\
\text { (2017) }\end{array}$ & $\begin{array}{l}\text { Review } \\
\text { Study }\end{array}$ & $\begin{array}{l}\text { Researcher } \\
\text { (Content } \\
\text { Analysis) }\end{array}$ & $\begin{array}{l}13 \text { academic } \\
\text { articles in } 3 \\
\text { scientific } \\
\text { databases }\end{array}$ & $\begin{array}{l}\text { There is a negative } \\
\text { association } \\
\text { between emotional } \\
\text { intelligence and } \\
\text { burnout. }\end{array}$ \\
\hline
\end{tabular}




\begin{tabular}{|c|c|c|c|c|c|}
\hline 4 & $\begin{array}{l}\text { Saleem et al. } \\
\text { (2017) }\end{array}$ & Quantitative & $\begin{array}{l}\text { Survey } \\
\text { Questionnaire }\end{array}$ & $\begin{array}{l}50 \text { principals, } 300 \\
\text { teachers-Pakistan }\end{array}$ & $\begin{array}{l}\text { Democratic } \\
\text { leadership style is } \\
\text { preferred by the } \\
\text { principals. They } \\
\text { also observed a } \\
\text { significant } \\
\text { relationship } \\
\text { between } \\
\text { leadership styles } \\
\text { (EI and POS) and } \\
\text { organizational } \\
\text { commitment. }\end{array}$ \\
\hline 5 & $\begin{array}{l}\text { Makhbul and } \\
\text { Khairuddin } \\
(2013)\end{array}$ & $\begin{array}{l}\text { Review } \\
\text { study }\end{array}$ & $\begin{array}{l}\text { Content } \\
\text { analysis }\end{array}$ & $\begin{array}{l}\text { Malaysian } \\
\text { academicians }\end{array}$ & $\begin{array}{l}\text { Both } \\
\text { environmental } \\
\text { factors and } \\
\text { personal factors } \\
\text { affect the } \\
\text { academicians' } \\
\text { wellbeing. }\end{array}$ \\
\hline 6 & $\begin{array}{l}\text { Bakker et al. } \\
\text { (2010) }\end{array}$ & Quantitative & $\begin{array}{l}\text { Survey } \\
\text { Questionnaire }\end{array}$ & $\begin{array}{l}3753 \text { Australian } \\
\text { Academicians }\end{array}$ & $\begin{array}{l}\text { Neuroticism } \\
\text { correlates with the } \\
\text { health impairment } \\
\text { process, and that } \\
\text { extroversion } \\
\text { correlates with } \\
\text { motivational } \\
\text { process. }\end{array}$ \\
\hline 7 & $\begin{array}{l}\text { Watts and } \\
\text { Robertson } \\
(2011)\end{array}$ & $\begin{array}{l}\text { Qualitative } \\
\text { content } \\
\text { analysis }\end{array}$ & Researcher & $\begin{array}{l}6 \text { valid databases. } \\
\text { No human } \\
\text { participation-Glob } \\
\text { al }\end{array}$ & $\begin{array}{l}\text { Burnout is the } \\
\text { result of having } \\
\text { large classes with } \\
\text { many students. } \\
\text { Gender and age } \\
\text { also played a } \\
\text { predictive role as } \\
\text { female staff and } \\
\text { younger staff were } \\
\text { more subject to } \\
\text { burnout. They } \\
\text { correlated this to } \\
\text { emotional } \\
\text { exhaustion of the } \\
\text { female staff. }\end{array}$ \\
\hline 8 & $\begin{array}{l}\text { Prieto et al. } \\
(2008)\end{array}$ & $\begin{array}{l}\text { Quantitative } \\
\text { survey }\end{array}$ & $\begin{array}{l}\text { Survey } \\
\text { Questionnaire }\end{array}$ & 274 teachers-Spain & $\begin{array}{l}\text { Quantitative } \\
\text { overload has a } \\
\text { predictive impact } \\
\text { on exhaustion and } \\
\text { dedication. It was } \\
\text { also realized that } \\
\text { role conflict } \\
\text { impacts cynicism } \\
\text { and role ambiguity } \\
\text { impacts } \\
\text { dedication. }\end{array}$ \\
\hline 9 & $\begin{array}{l}\text { Winefield et al. } \\
\text { (2003) }\end{array}$ & $\begin{array}{l}\text { Quantitative } \\
\text { survey }\end{array}$ & $\begin{array}{l}\text { Survey } \\
\text { questionnaire }\end{array}$ & $\begin{array}{l}9000 \text { academic } \\
\text { staff -Australia }\end{array}$ & $\begin{array}{l}\text { The academic staff } \\
\text { were worse off } \\
\text { than general staff. } \\
\text { The new staff were } \\
\text { worse off than the }\end{array}$ \\
\hline
\end{tabular}




\begin{tabular}{|c|c|c|c|c|}
\hline & & & & $\begin{array}{l}\text { older staff in terms } \\
\text { of strain and job } \\
\text { satisfaction. } \\
\text { Psychological } \\
\text { wellbeing was } \\
\text { highly correlated } \\
\text { with objective } \\
\text { measures of } \\
\text { university } \\
\text { wellbeing. }\end{array}$ \\
\hline $\begin{array}{l}10 \quad \text { Ismail et al. } \\
(2009)\end{array}$ & Quantitative & $\begin{array}{l}\text { Survey } \\
\text { Questionnaire }\end{array}$ & $\begin{array}{l}104 \\
\text { Academicians- } \\
\text { Private } \\
\text { Universities } \\
\text { Kuching }\end{array}$ & $\begin{array}{l}\text { Occupational } \\
\text { stress and job } \\
\text { performance } \\
\text { correlate, and } \\
\text { emotional } \\
\text { intelligence play a } \\
\text { significant role } \\
\text { and mediates the } \\
\text { relationship. }\end{array}$ \\
\hline
\end{tabular}

The review of previous studies also highlights that the quantitative design is the mostly used research design. The main form of instrument used in these studies is that of a Likert-scale questionnaire.

\section{Methods}

This section clarifies the methodology progress adopted by this study, which explains the research design, population and sampling, and the instrumentation.

\subsection{Research Design}

This quantitative study has a cross-sectional design, as data were collected through distributing Google forms. Spector (2019) argues that cross-sectional design provides much valuable information that explains the relationship among the model variables, specifically the lack of temporal components. As a quantitative study, the study has its roots in the positivist perspective that considers reality as observed rather than perceived (Crossan, 2003).

\subsection{Population and Sampling}

To conduct the study, the researchers made use of five research universities in the context of Malaysia, i.e., University of Malaya (UM), University of Putra Malaysia (UPM), University of Teknologi Malaysia (UTM), University of Kebangsaan Malaysia (UKM), and University Sains Malaysia (USM). The total of academic staff determined at 2,000 as reported by the Malaysian Ministry of Education. These universities were entitled Malaysian Research Universities (MRUs) (MOHE, 2007). The researchers targeted the academic leaders at various positions and sent the questionnaire to about 2000 academic staff, which is processed via the human resource department of each university, the generated link from the Google survey platform posted to the academic leaders' social network community of these universities. As a result, out of which, 250 respondents replied. The probability sampling technique was used to lower the sampling bias, and to ensure sampling diversification as suggested by Acharya et al. (2013), which provides better understanding of the population perspective. 


\subsection{Instruments}

The Likert scale questionnaire was used in this study. The questionnaire had 81 items. It was a combination of 7 different Likert scale questionnaires. However, as this study is part of a larger study, only the questions relevant to this study are discussed. The items relevant to job demand were chosen from "Copenhagen Psychosocial Questionnaire; COPSOQ II" (Pejtersen et al., 2010). The questionnaire entails questions relaxant to cognitive, physical, and emotional job demands. Items relevant to burnout were selected from "Copenhagen Burnout Inventory; CBI", to assess academics burnout (Kristensen et al., 2005). Finally, the items related to job performance (in-role and extra-role) were selected from Williams and Anderson (1991).

\section{Results}

The objectives behind this study were threefold. First, it aimed at exploring the effects of physical, emotional, and cognitive demands on the burnout of academicians. Second, it investigated the effect of burnout on in-role and extra-role of academicians; and finally, it studied to what extent burnout mediated the effect of physical, emotional, and cognitive demands on in-role and extra-role.

The data collected in this study were analyzed using SmartPLS V. 3.2.8. All results were bootstrapped 1,000 times to compute confidence intervals for the computed indices. The conceptual model being explored is displayed in Figure 4.1. As displayed in this model, the physical, cognitive, and emotional demands directly affect burnout. They also have indirect effects on in-role and extra-role through the mediation of burnout. Some of the indicators (items) related to latent variables were dropped out, which will be discussed below.

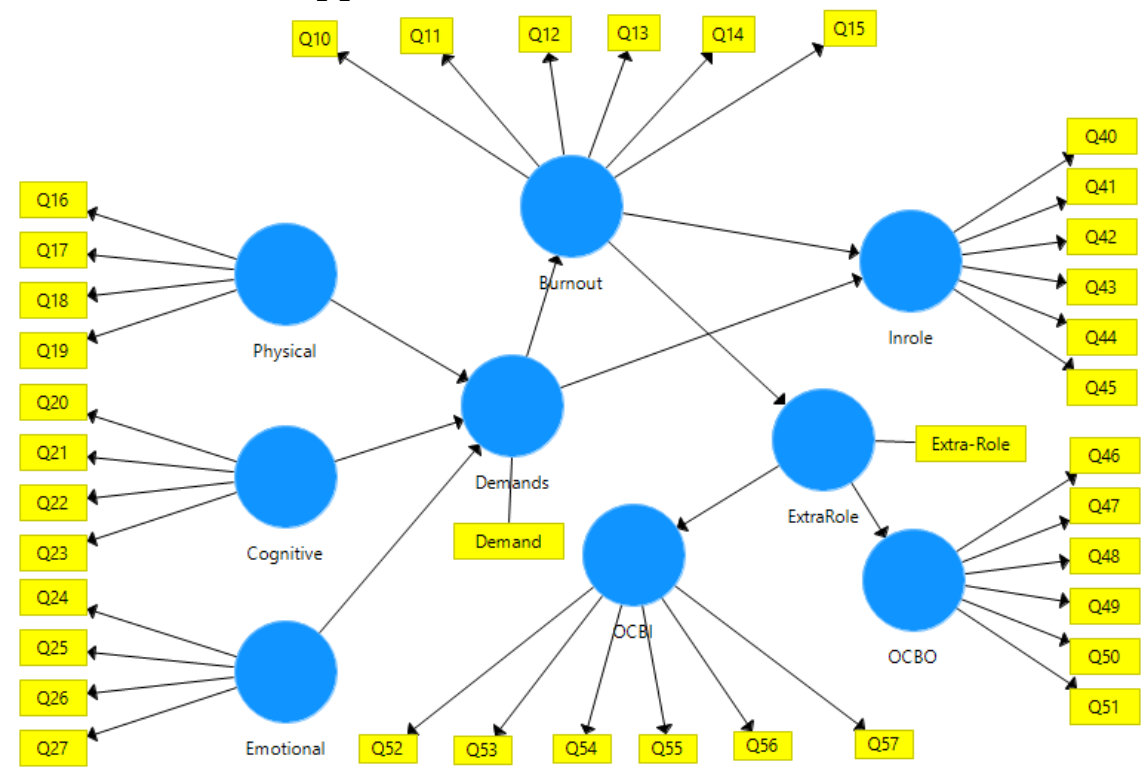

Figure 2: Conceptual PLS model 


\subsection{Cronbach's Alpha and Composite Reliability Indices}

Cronbach's alpha and composite reliability (CR) indices were computed for the components of the present model. Both Cronbach's alpha and CR, which are complementary indices, were reported because, as noted by (Hair et al., 2017, p. 112), Cronbach's alpha is a conservative measure of reliability (i.e., it results in relatively low-reliability values). In contrast, composite reliability tends to overestimate the internal consistency reliability, thereby resulting in comparatively higher reliability estimates. Therefore, it is reasonable to consider and report both criteria. When analyzing and assessing the measures' internal consistency reliability, the true reliability usually lies between Cronbach's alpha (representing the lower bound) and the composite reliability (representing the upper bound)".

Cronbach's alpha reliability indices should be equal to or higher than .70, as suggested by Tseng et al. (2006) and Dörnyei and Taguchi (2009). Except for OCBO, all other constructs enjoyed Cronbach's alpha indices higher than .70; moreover, all probabilities were lower than .05, and none of the confidence intervals were negative or zero. Although OCBO's reliability index of .589 was lower than .70 , it enjoyed a statistical significance $(p=.000)$, and its confidence intervals of .412 and .694 were neither negative nor zero. Based on these results, it can be concluded that the present constructs enjoyed statistically significant Cronbach's alpha reliability indices.

Table 2: Cronbach's Alpha reliability indices

\begin{tabular}{llllllll}
\hline & \multirow{2}{*}{ Alpha } & \multirow{2}{*}{ Mean } & \multirow{2}{*}{ SD } & t-value & p-value & \multicolumn{2}{c}{ Confidence Intervals } \\
\hline Burnout & 0.889 & 0.888 & 0.015 & 57.753 & 0.000 & 0.854 & $\mathbf{9 7 . 5 \%}$ \\
Cognitive & 0.766 & 0.760 & 0.040 & 19.071 & 0.000 & 0.673 & 0.829 \\
Emotional & 0.812 & 0.811 & 0.027 & 29.724 & 0.000 & 0.752 & 0.856 \\
In-Role & 0.755 & 0.746 & 0.059 & 12.891 & 0.000 & 0.609 & 0.828 \\
OCBI & 0.844 & 0.842 & 0.025 & 33.629 & 0.000 & 0.784 & 0.885 \\
OCBO & 0.589 & 0.578 & 0.075 & 7.821 & 0.000 & 0.412 & 0.694 \\
Physical & 0.724 & 0.722 & 0.037 & 19.393 & 0.000 & 0.640 & 0.787 \\
\hline
\end{tabular}

Table 3 displays the CR indices for the present data. Composite reliability indices should be equal to or higher than .60; however, they should not be higher than 0.95 (Hair et al. 2016, p. 112). As displayed in Table 3, all CR indices were within the ranges of .60 to .95 , they all enjoyed statistical significance, and all confidence intervals were positive and non-zero. Thus, it can be concluded that the present constructs enjoyed significant CR indices.

Table 3: Composite reliability indices

\begin{tabular}{llllllll}
\hline & \multirow{2}{*}{$\begin{array}{l}\text { Composite } \\
\text { Reliability }\end{array}$} & Mean & SD & t-value & p-value & \multicolumn{2}{l}{$\begin{array}{l}\text { Confidence } \\
\text { Intervals }\end{array}$} \\
\cline { 5 - 8 } & & & & & $\mathbf{2 . 5 \%}$ & $\mathbf{9 7 . 5 \%}$ \\
\hline Burnout & 0.916 & 0.915 & 0.011 & 84.694 & 0.000 & 0.891 & 0.933 \\
Cognitive & 0.851 & 0.848 & 0.022 & 38.997 & 0.000 & 0.802 & 0.887
\end{tabular}




\begin{tabular}{llllllll} 
Emotional & 0.877 & 0.877 & 0.015 & 56.857 & 0.000 & 0.844 & 0.903 \\
In-Role & 0.721 & 0.578 & 0.272 & 2.653 & 0.008 & 0.005 & 0.863 \\
OCBI & 0.885 & 0.884 & 0.016 & 54.970 & 0.000 & 0.848 & 0.913 \\
OCBO & 0.735 & 0.731 & 0.038 & 19.593 & 0.000 & 0.649 & 0.790 \\
Physical & 0.827 & 0.824 & 0.022 & 37.714 & 0.000 & 0.778 & 0.863 \\
\hline
\end{tabular}

\subsection{Average Variance Extracted}

The average variance extracted (AVE) for the components of the model were computed. As noted by Garson (2016), AVE indices should be at least equal to .50. The average variance extracted indicates the probability that the construct is measuring what it is supposed to measure. For example, the AVE for burnout was .644. That is to say, there was a 64.4 percent chance that burnout measured what it was supposed to measure. The results indicated that the AVE for all constructs was higher than .50, except for in-role and OCBO. Despite these low AVE indices, all results were statistically significant; i.e. $p=.000$, and none of the confidence intervals were negative or zero. Thus, it can be concluded that the constructs of this model enjoyed significant AVE indices.

Table 4: Average variance extracted

\begin{tabular}{llllllll}
\hline & \multirow{2}{*}{ AVE } & \multirow{2}{*}{ Mean } & \multirow{2}{*}{ SD } & t-value & p-value & \multicolumn{2}{c}{ Confidence Intervals } \\
\cline { 7 - 8 } & & & & & & $\mathbf{2 . 5} \%$ & $\mathbf{9 7 . 5} \%$ \\
\hline Burnout & 0.644 & 0.643 & 0.031 & 20.522 & 0.000 & 0.577 & 0.701 \\
Cognitive & 0.588 & 0.585 & 0.040 & 14.522 & 0.000 & 0.507 & 0.662 \\
Emotional & 0.643 & 0.643 & 0.032 & 19.971 & 0.000 & 0.578 & 0.701 \\
In-Role & 0.332 & 0.355 & 0.074 & 4.475 & 0.000 & 0.261 & 0.515 \\
OCBI & 0.564 & 0.563 & 0.038 & 14.851 & 0.000 & 0.485 & 0.636 \\
OCBO & 0.322 & 0.322 & 0.037 & 8.637 & 0.000 & 0.247 & 0.391 \\
Physical & 0.565 & 0.566 & 0.029 & 19.287 & 0.000 & 0.503 & 0.623 \\
\hline
\end{tabular}

\subsection{Exploring Outer Loadings}

In a PLS model, outer loadings refer to the contribution of indicators (items) to the latent variables. Based on the results displayed in Table 6, it can be concluded that all indicators had significant $(p<.05)$ contributions to their latent variables, except for the four of the items related to in-role, i.e., items 40 to 43.

Table 5: Outer loadings

\begin{tabular}{llllllll} 
& $\begin{array}{l}\text { Outer } \\
\text { Loadings }\end{array}$ & $\mathbf{M}$ & SD & $\begin{array}{l}\text { t-valu } \\
\text { e }\end{array}$ & $\begin{array}{l}\text { p-val } \\
\text { ue }\end{array}$ & $\mathbf{2 . 5 0 \%}$ & $\begin{array}{l}\mathbf{2 7 . 5 0} \\
\mathbf{0}\end{array}$ \\
\hline Q10 <- Burnout & 0.816 & 0.815 & 0.030 & 27.111 & 0.000 & 0.751 & 0.869 \\
Q11 <- Burnout & 0.810 & 0.807 & 0.031 & 26.313 & 0.000 & 0.738 & 0.859 \\
Q12 <- Burnout & 0.831 & 0.830 & 0.024 & 34.833 & 0.000 & 0.781 & 0.868 \\
Q13 <- Burnout & 0.817 & 0.814 & 0.031 & 26.486 & 0.000 & 0.742 & 0.862 \\
Q14 <- Burnout & 0.766 & 0.767 & 0.030 & 25.150 & 0.000 & 0.701 & 0.821 \\
Q15 <- Burnout & 0.771 & 0.773 & 0.030 & 25.442 & 0.000 & 0.709 & 0.824 \\
Q16 <- Physical & 0.832 & 0.833 & 0.024 & 35.300 & 0.000 & 0.784 & 0.874 \\
Q17 <- Physical & 0.889 & 0.889 & 0.016 & 54.123 & 0.000 & 0.853 & 0.918
\end{tabular}




\begin{tabular}{|c|c|c|c|c|c|c|c|}
\hline Q18 <- Physical & 0.808 & 0.806 & 0.034 & 23.652 & 0.000 & 0.734 & 0.864 \\
\hline Q19 <- Physical & 0.354 & 0.338 & 0.113 & 3.125 & 0.002 & 0.091 & 0.539 \\
\hline Q20 <- Cognitive & 0.714 & 0.710 & 0.051 & 14.115 & 0.000 & 0.599 & 0.794 \\
\hline Q21 <- Cognitive & 0.805 & 0.805 & 0.027 & 29.466 & 0.000 & 0.746 & 0.852 \\
\hline Q22 <- Cognitive & 0.771 & 0.762 & 0.046 & 16.796 & 0.000 & 0.656 & 0.840 \\
\hline Q23 <- Cognitive & 0.775 & 0.774 & 0.030 & 25.911 & 0.000 & 0.706 & 0.824 \\
\hline Q24 <- Emotional & 0.761 & 0.760 & 0.036 & 21.323 & 0.000 & 0.682 & 0.822 \\
\hline Q25 <- Emotional & 0.769 & 0.767 & 0.037 & 20.573 & 0.000 & 0.683 & 0.832 \\
\hline Q26 <- Emotional & 0.899 & 0.900 & 0.013 & 70.789 & 0.000 & 0.873 & 0.922 \\
\hline Q27 <- Emotional & 0.769 & 0.770 & 0.032 & 24.176 & 0.000 & 0.701 & 0.827 \\
\hline Q40 <- In-role & 0.393 & 0.287 & 0.363 & 1.083 & 0.279 & -0.482 & 0.759 \\
\hline Q41 <- In-role & 0.361 & 0.246 & 0.397 & 0.909 & 0.364 & -0.574 & 0.775 \\
\hline Q42 <- In-role & 0.374 & 0.259 & 0.388 & 0.962 & 0.336 & -0.540 & 0.778 \\
\hline Q43 <- In-role & 0.434 & 0.317 & 0.380 & 1.142 & 0.254 & -0.490 & 0.814 \\
\hline Q44 <- In-role & 0.830 & 0.756 & 0.233 & 3.563 & 0.000 & 0.418 & 0.937 \\
\hline Q45 <- In-role & 0.830 & 0.750 & 0.216 & 3.848 & 0.000 & 0.454 & 0.920 \\
\hline Q46 <- OCBO & 0.437 & 0.433 & 0.082 & 5.333 & 0.000 & 0.249 & 0.563 \\
\hline Q47<- OCBO & 0.624 & 0.622 & 0.052 & 11.975 & 0.000 & 0.507 & 0.706 \\
\hline Q48<- OCBO & 0.625 & 0.617 & 0.072 & 8.727 & 0.000 & 0.450 & 0.733 \\
\hline Q49<- OCBO & 0.473 & 0.472 & 0.069 & 6.823 & 0.000 & 0.319 & 0.586 \\
\hline Q50 <- OCBO & 0.679 & 0.677 & 0.042 & 16.009 & 0.000 & 0.583 & 0.750 \\
\hline Q51<- OCBO & 0.524 & 0.522 & 0.060 & 8.739 & 0.000 & 0.397 & 0.625 \\
\hline Q52 <- OCBI & 0.769 & 0.769 & 0.028 & 27.462 & 0.000 & 0.711 & 0.819 \\
\hline Q53 <- OCBI & 0.711 & 0.711 & 0.041 & 17.392 & 0.000 & 0.628 & 0.782 \\
\hline Q54 <- OCBI & 0.752 & 0.750 & 0.038 & 19.804 & 0.000 & 0.664 & 0.815 \\
\hline Q55 <- OCBI & 0.743 & 0.741 & 0.036 & 20.795 & 0.000 & 0.664 & 0.808 \\
\hline Q56 <- OCBI & 0.827 & 0.825 & 0.027 & 30.427 & 0.000 & 0.764 & 0.869 \\
\hline Q57 <- OCBI & 0.695 & 0.692 & 0.049 & 14.277 & 0.000 & 0.588 & 0.777 \\
\hline
\end{tabular}

\subsection{Exploring Direct Effects (First Four Research Questions)}

The first four research questions explored the direct effects of physical, cognitive and emotional demands on burnout; and direct effects of burnout on in-role and extra-role. Table 6 and Figure 3 display the standardized path coefficients. Based on these results, it can be concluded that;

A: Physical demand had a significant direct effect on burnout $(b=.161, t=8.75$, $\mathrm{p}=.000,97.5 \%$ CI $[.120, .194])$. Thus, it can be concluded that the first null-hypothesis was rejected.

B: Emotional demand had a significant direct effect on burnout $(b=.258, t=$ $10.04, \mathrm{p}=.000,97.5 \% \mathrm{CI}[.194, .300])$. Thus, it can be concluded that the second null-hypothesis was rejected.

C: Cognitive demand had significant direct effect on burnout $(b=.249, t=7.91, p$ $=.000,97.5 \%$ CI $[.179, .303])$. Thus, it can be concluded that the third null-hypothesis was rejected. 
Table 6: Direct effects (research questions one to four)

\begin{tabular}{llllllll}
\hline & $\begin{array}{l}\text { Direct } \\
\text { Effect }\end{array}$ & M & SD & t-Value & $\begin{array}{l}\text { P } \\
\text { Values }\end{array}$ & $\mathbf{2 . 5 \%}$ & $\mathbf{9 7 . 5 \%}$ \\
\hline Burnout -> Extra-Role & 0.213 & 0.209 & 0.085 & 2.491 & 0.013 & 0.040 & 0.385 \\
Burnout -> In-Role & 0.314 & 0.320 & 0.100 & 3.133 & 0.002 & 0.185 & 0.442 \\
Cognitive -> Burnout & 0.249 & 0.247 & 0.031 & 7.918 & 0.000 & 0.179 & 0.303 \\
Emotional -> Burnout & 0.258 & 0.255 & 0.026 & 10.046 & 0.000 & 0.194 & 0.300 \\
Physical -> Burnout & 0.161 & 0.161 & 0.018 & 8.750 & 0.000 & 0.120 & 0.194 \\
\hline
\end{tabular}

D: Burnout had a significant direct effect on in-role $(b=.314, t=3.13, p=.002$, $97.5 \%$ CI $[.185, .442]) ;$ and extra-role $(b=.213, t=2.49, \mathrm{p}=.013,97.5 \%$ CI [.040, .385]). Based on these results, it can be concluded that the fourth null-hypothesis was rejected, although the results should be interpreted cautiously due to the near zero lower bound confidence interval of .040 for the direct effect of burnout on extra-role.

Figure 3 displays the direct and indirect effects of the PLS model. The values on the arrows are standardized path coefficients.

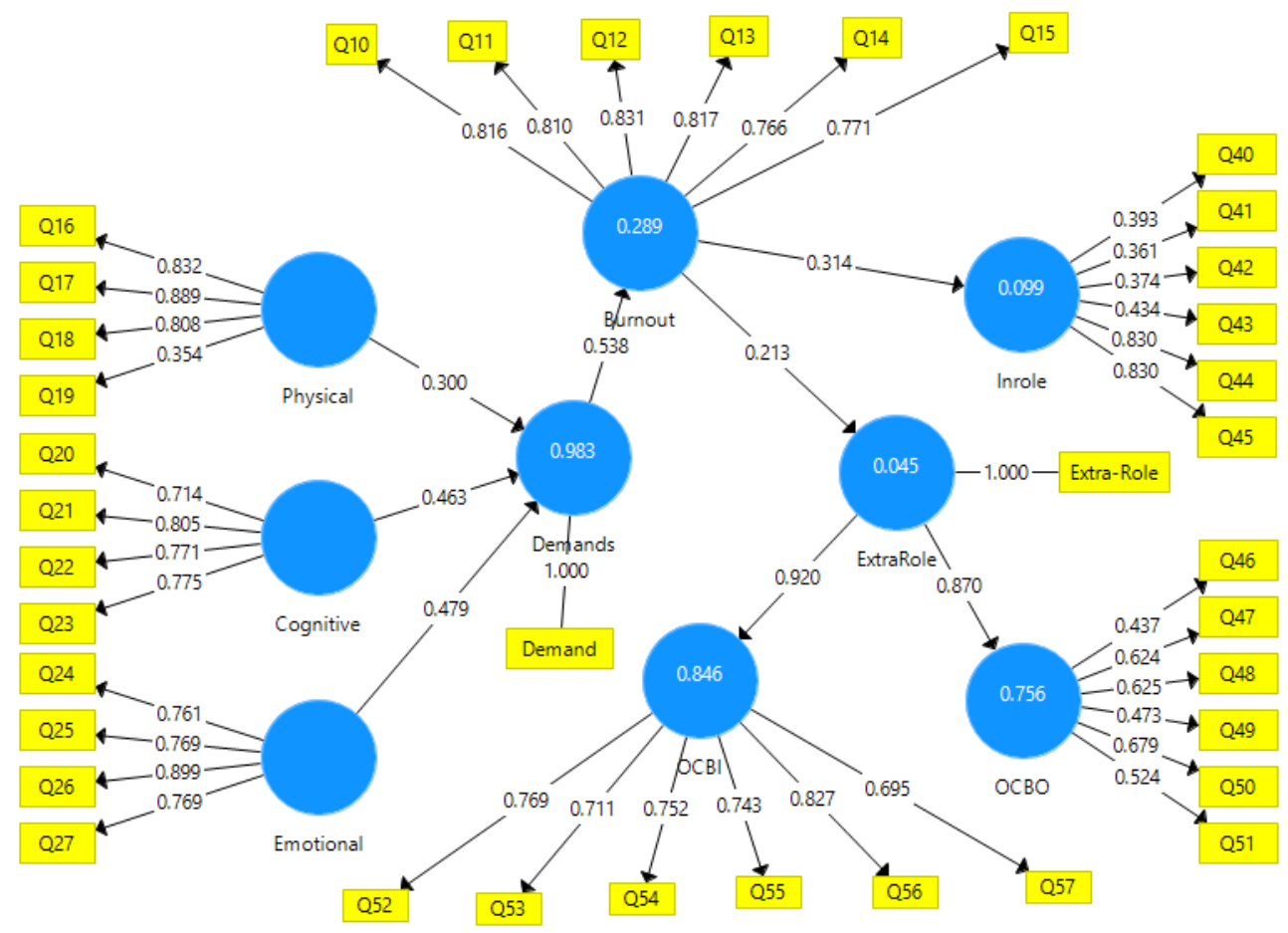

Figure 3: Final PLS model (standardized path coefficients)

\subsection{Exploring Indirect Effects (Fifth Research Question)}

The last research question explored the indirect effects of demands on in-role and extra-role through the mediation of burnout. Based on the results displayed in Table 8, it can be concluded that;

Demands had significant indirect effect on in-role after being mediated with burnout $(\mathrm{b}=.169, \mathrm{t}=2.807, \mathrm{p}=.005,97.5 \% \mathrm{CI}[.086, .277])$. It also had a significant indirect effect on extra-role after being mediated with burnout $(\mathrm{b}=$ 
$.114, \mathrm{t}=2.05, \mathrm{p}=.040,97.5 \% \mathrm{CI}[.018, .242])$. Thus, it can be concluded that the fifth null-hypothesis was rejected, although the results should be interpreted cautiously because the lower bound confidence intervals for these indirect effects were almost zero; i.e. .086 and .018.

Table 7: Indirect effects (fifth research question)

\begin{tabular}{|c|c|c|c|c|c|c|c|}
\hline & $\begin{array}{l}\text { Indirect } \\
\text { Effect }\end{array}$ & $\mathbf{M}$ & SD & $\begin{array}{l}\text { t-Valu } \\
\text { e }\end{array}$ & $\begin{array}{l}\mathbf{P} \\
\text { Values } \\
\end{array}$ & $2.5 \%$ & $97.5 \%$ \\
\hline $\begin{array}{l}\text { Demands }->\text { Burnout } \\
\text {-> In-Role }\end{array}$ & 0.169 & 0.173 & 0.060 & 2.807 & 0.005 & .086 & .277 \\
\hline $\begin{array}{l}\text { Demands }->\text { Burnout } \\
->\text { Extra-Role }\end{array}$ & 0.114 & 0.115 & 0.056 & 2.056 & 0.040 & .018 & .242 \\
\hline
\end{tabular}

Figure 4 displays the final model. The relationships between variables are displayed as t-values.

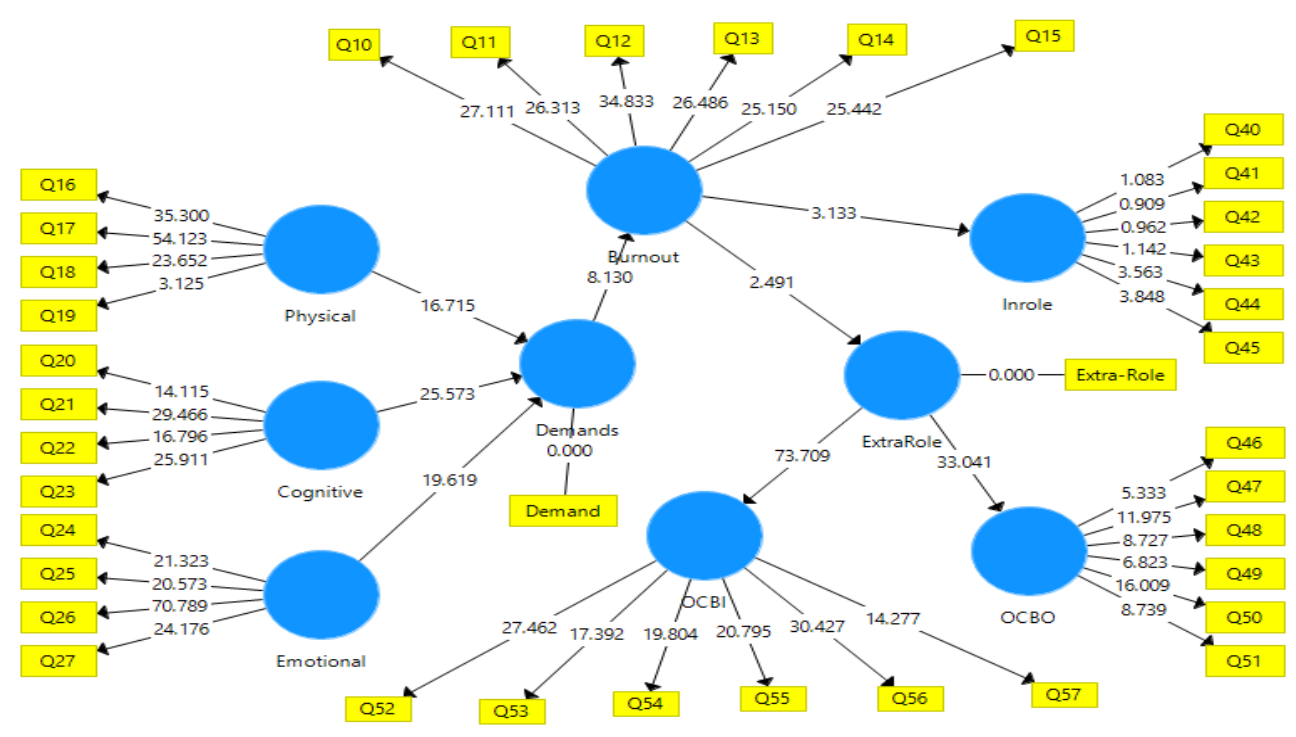

Figure 4: Final PLS model (t-values)

\section{Discussions}

The findings of this study are generally in line with the previously published documents. Numerous resources have been reported on the effects of job demands (i.e., cognitive, emotional, and physical) on burnout. In most cases, these studies have observed significant positive effects (e.g., Bakker et al., 2010; Ismail et al., 2009; Kasinathan and Arokiasamy (2019); Makhbul \& Khairuddin, 2013; Mérida-López \& Extremera, 2017; Prieto et al., 2008; Saleem et al., 2017; Watts \& Robertson, 2011; Winefield et al., 2003; Zysberg et al., 2017). For example, Kasinathan and Arokiasamy (2019), who studied Malaysian academicians' well-being, realized that emotional and psychological wellbeing affects the profitability of Malaysian Universities. Therefore, they suggested enough attention to the emotional and psychological aspects of the academicians' job demands. Elsewhere, Zysberg et al. (2017) associated burnout with emotions and personality. This study was also conducted among academic leaders at RUs. Congruent with these two studies, it was realized that the 
emotional aspect of academic staffs' job demand in research universities could affect their burnout at work.

Various aspects of job demands at Malaysian universities were studied by Makhbul and Khairuddin (2013) who realized that excessive job demands (psychical, emotional, and psychological) are the main resources of job-related stress which eventually reduces job performance. They also mention that burnout is the result of stress. Similar results were found in the current study where emotional, physical, and cognitive demands showed significant effects on burnout among Malaysian academicians at research universities. Also, it was observed that burnout could affect the in-role and extra-role performance of the Malaysian academicians at RUs. The findings are in line with the majority of previous studies, as they have observed a direct effect of burnout on performance. For example, Brown and Roloff (2013); Petitta and Vecchione (2011) observed a direct effect of burnout on extra-role performance. These two studies were conducted in the educational and non-educational sectors respectively; however, they both showed a decrease in commitment due to burnout. Thus, the findings are in line with the current study. Watts and Robertson (2011) posit that burnout might be found in different occupations; however, only excessive burnout can affect performance, as it causes emotional stress. This indicates that the working situation in Malaysian research universities should be restudied to make sure it does not cause emotional stress.

A direct impact on in-role performance was also observed as a result of burnout. In line with this finding, the impact of burnout on in-role performance was already observed among bank employees (Yavas et al., 2013), flight attendants (Chen \& Kao, 2012), and teachers (Cohen \& Abedallah, 2015). Therefore, it can be concluded that the findings of the current study are congruent with the main trends in the literature on burnout and performance.

Burnout showed a mediating role between job demands and performance. The majority of previous studies see burnout as the main result of job-related stress (e.g., Cohen \& Abedallah, 2015; Makhbul \& Khairuddin, 2013; Watts \& Robertson, 2011). For example, Watts and Robertson (2011) assert that burnout causes emotional stress and emotional stress affects performance. Cohen and Abedallah (2015) also mentioned that burnout mediates the relationship of between EI and self-efficacy among teachers. Congruent with such views concerning burnout, in this study, the researchers observed that burnout could mediate the impact of job demands on job performance, although this study was not an attempt to realize what causes such a mediation. Some scholars such as Celik (2013) believe that where job performance is negatively affected, there is a sign of burnout. He made this conclusion by looking into role ambiguity among teachers, which causes burnout and affects performance. In his study, burnout was observed as a mediating role.

The findings of this study are also in line with the results gained in some other fields. The mediating role of burnout on job performance has also been observed in other work environments. For example, Leiter and Maslach (2009) 
supported the mediation model of burnout, in which areas of work-life predicted burnout.

\section{Conclusion}

In this study, the effects of various job demands on burnout among Malaysian academic leaders at RUs were observed. The job demand included emotional, cognitive, and physical demands which prove to have significant impacts on burnout among the target population. These demands were dealt with at individual level. In addition, the impact of burnout on in-role and extra-role performance of Malaysian academicians was observed. This impact was significant for both in-role and extra-role performance. In addition, the mediating (indirect) effect of burnout between job demands and performance was significant. This indicates that the effect of burnout on performance has a direct and an indirect effect.

This study was a response to a need for a research on Malaysian RUs in line with the high demands on the academicians in these institutes of higher education. The findings can be practical for policymakers who are held accountable for making leadership decisions in these universities. In addition, the educational syllabus designers who set the educational syllabus for each educational year should bear in mind that high physical, emotional, and even cognitive demand posed through long working hours can result in burnout among the academicians. This study is limited to the MRUs. This is due to the high concerns of Malaysian higher education about this category of universities, besides the high need for cognitive demand to be tested in the context of research universities category. It is highly recommended that the Malaysian higher education pays much attention to boosting the emotional demand within the academicians, as it has the highest reduction impact on burnout. It is highly suggested that the prospective researchers should focus on strategies to reduce burnout among academic leaders. These strategies should be well studied so that they can be used in educational contexts.

\section{References}

Al-Dubai, S. A. R., Ganasegeran, K., Perianayagam, W., \& Rampal, K. G. (2013). Emotional burnout, perceived sources of job stress, professional fulfillment, and engagement among medical residents in Malaysia. The Scientific World Journal, 11(2), 86. https://doi.org/10.1155/2013/137620

Acharya, A. S., Prakash, A., Saxena, P., \& Nigam, A. (2013). Sampling: Why and how of it. Indian journal of medical specialities, 4(2), 330-333. https://doi.org/10.7713/ijms.2013.0032

Arbae, M. N. A., Othman, N. A. M., Mahamad, N. F., Bakri, S. F. Z., \& Hariri, A. (2019). Study of perceived stress among academicians in higher institutional Malaysia. $\begin{array}{lllll}\text { Journal of Safety, Health } \mathcal{E} \text { Ergonomics, } & \text { 1(1). }\end{array}$ http://fazpublishing.com/jshe/index.php/jshe/article/view/4

Bakker, A. B., Boyd, C. M., Dollard, M., Gillespie, N., Winefield, A. H., \& Stough, C. (2010). The role of personality in the job demands-resources model. Career Development International. https:// doi.org/10.1108/13620431011094050

Bakker, A. B., \& Demerouti, E. (2007). The job demands - resources model: State of the art. Journal of Managerial Psychology. https://doi.org/10.1108/02683940710733115 
Bakker, A. B., \& Demerouti, E. (2014). Job demands-resources theory. Wellbeing: A complete reference guide, 1-28. https:/ / doi.org/10.1002/9781118539415.wbwell019

Bakker, A. B., \& Demerouti, E. (2017). Job demands-resources theory: taking stock and looking forward. Journal of occupational health psychology, 22(3), 273. http://dx.doi.org/10.1037/ocp0000056

Bakker, A. B., \& Demerouti, E. (2018). Multiple levels in job demands-resources theory: Implications for employee well-being and performance. In Handbook of well-being. DEF Publishers. https://doi.org.nobascholar.com

Brown, L. A., \& Roloff, M. E. (2015). Organizational citizenship behavior, organizational communication, and burnout: The buffering role of perceived organizational support and psychological contracts. Communication Quarterly, 63(4), 384-404. https:// doi.org/10.1080/01463373.2015.1058287

Bowen, P., Rose, R., \& Pilkington, A. (2016). Perceived stress amongst university academics. American International Journal of Contemporary Research, 6(1), 22-28. http://www.aijcrnet.com/journals/Vol_6_No_1_February_2016/3.pdf

Bte Marmaya, N. H., Hitam, M., Zawawi, N., \& Jody, J. M. (2011). Organizational commitment and job burnout among employees in Malaysia. Proc Intl Conf on Bus and Econs Res, 185-187. http:/ / www.ipedr.com/vol1/40-B10039.pdf

Burkinshaw, P., \& White, K. (2019). Networking and gender equality in academic leadership. In Women, Business and Leadership. Edward Elgar Publishing. https://doi.org/10.4337/9781786432711.00017

Celik, K. (2013). The effect of role ambiguity and role conflict on performance of vice principals: The mediating role of burnout. Eurasian Journal of Educational Research, 51, 195-213. https:/ files.eric.ed.gov/fulltext/EJ1059818.pdf

Chen, C. F., \& Kao, Y. L. (2012). Moderating effects of work engagement and job tenure on burnout-performance among flight attendants. Journal of Air Transport Management, 25, 61-63. https://doi.org/10.1016/j.jairtraman.2012.08.009

Cohen, A., \& Abedallah, M. (2015). The mediating role of burnout on the relationship of emotional intelligence and self-efficacy with OCB and performance. Management Research Review. https:/ / doi.org/10.1108/MRR-10-2013-0238

Crossan, F. (2003). Research philosophy: Towards an understanding. Nurse Researcher, 11(1), 46.

DeFrank, R. S., \& Ivancevich, J. M. (1998). Stress on the job: An executive update. Academy of Management Executives, 12, 55-66. https://doi.org/10.5465/ame.1998.1109050

Dörnyei, Z., \& Taguchi, T. (2009). Questionnaires in second language research: Construction, administration, and processing. Routledge. http://golshanlc.com/wp-content/uploads/2019/09/Questionnaires_in_Secon d_Language_Research_Construction__Administration_and_Processing_Seco nd_Language_Acquisition_Research_Series_.pdf

Friedman, I. A. (2000). Burnout in teachers: Shattered dreams of impeccable professional performance. Journal of Clinical Psychology, 56(5), 595-606.

Fullan, M., \& Scott, G. (2009). Turnaround leadership for higher education. John Wiley \& Sons. https:/ / doi.org/10.2202/1940-1639.1687

Garson, G. D. (2016). Partial least squares: Regression and structural equation models. Statistical Associates Publishers. http:/ / www.statisticalassociates.com/pls-sem.htm

Grapragasem, S., Krishnan, A., \& Mansor, A. N. (2014). Current trends in Malaysian higher education and the effect on education policy and practice: An overview. International Journal of Higher Education, 3(1), 85-93. http:/ / dx.doi.org/10.5430/ijhe.v3n1p85 
Hair, J. J. F., Sarstedt, M., Matthews Lucy, M., \& Ringle Christian, M. (2016). Identifying and treating unobserved heterogeneity with FIMIX-PLS: part I - method. European Business Review, 28(1), 63-76. http://doi.org/10.1108/EBR-09-2015-0094

Hair, J. F., Jr., Hult, G. T. M., Ringle, C., \& Sarstedt, M. (2017). A primer on partial least squares structural equation modeling (PLS-SEM). Sage publications. https://us.sagepub.com/en-us/nam/a-primer-on-partial-least-squares-structur al-equation-modeling-pls-sem/book 244583

House, R. J. (1971). A path goal theory of leader effectiveness. Administrative Science Quarterly, 321-339.

House, R. J. (1996). Path-goal theory of leadership: Lessons, legacy, and a reformulated theory. The Leadership Quarterly, 7(3), 323-352. https://doi.org/10.1016/S1048-9843(96)90024-7

House, R. J., \& Dessler, J. (1974). The pathgoal theory of leadership: Some post hoc and a priori tests. In J. G. Hunt \& L. L. Larson (Eds.), Contingency approaches to leadership, 29-55. Southern Illinois University Press. https://doi.org/10.2307/255527

Ilies, R., Huth, M., Ryan, A. M., \& Dimotakis, N. (2015). Explaining the links between workload, distress, and work-family conflict among school employees: Physical, cognitive, and emotional fatigue. Journal of Educational Psychology, 107(4), 1136. http://dx.doi.org/10.1037/edu0000029

Ismail, N. H., \& Noor, A. (2016). Occupational stress and its associated factors among academician in a research university, Malaysia. Malaysian Journal of Public Health Medicine, 16(1), 81-91.

Ismail, A., Suh-Suh, Y., Ajis, M. N. E., \& Dollah, N. F. (2009). Relationship between occupational stress, emotional intelligence and job performance: An empirical study in Malaysia. Theoretical \& Applied Economics, 16(10), 3-16.

Jex, S. M., Beehr, T. A., \& Roberts, C. K. (1992). The meaning of occupational stress items to survey respondents. Journal of Applied Psychology, 77(5), 623. https://doi.org/10.1037/0021-9010.77.5.623

Kasinathan, J. P., \& Arokiasamy, L. (2019). A Study on Academicians' Well-Being in Malaysian Universities: A Conceptual Paper. Global Business and Management Research, 11(1), 446-454.

Khairuddin, S. M. H. S., \& Makhbul, Z. K. M. (2011). Stress at the workplace and productivity: A pilot study on faculty administrators in a Malaysian research university. In proceedings of the 2nd International Conference on Business and Economic Research (2nd ICBER), Malaysia.

Kinman, G., \& Jones, F. (2005). Lay representations of workplace stress: What do people really mean when they say they are stressed? Work \& Stress, 19(2), 101-120. https://doi.org/10.1080/02678370500144831

Kristensen, T. S., Hannerz, H., Høgh, A., \& Borg, V. (2005). The Copenhagen Psychosocial Questionnaire-A tool for the assessment and improvement of the psychosocial work environment. Scandinavian Journal of Work, Environment $\mathcal{E}$ Health, 438-449. http://www.jstor.org/stable/40967527

Leiter, M. P., \& Maslach, C. (2009). Nurse turnover: The mediating role of burnout. Journal of Nursing Management, 17(3), 331-339. https:// doi.org/10.1111/j.1365-2834.2009.01004.x

Lorello, G. R., Cil, T., \& Flexman, A. M. (2020). Women anesthesiologists' journeys to academic leadership: A constructivist grounded theory-inspired study. Canadian Journal of Anaesthesia, 67(9), 1130-1139. https://doi.org/10.1007/s12630-020-01735-z

Madonko, N., \& April, K. A. (2020). The Effectiveness of Leaders in Communicating Organizational Values. Effective Executive, 23(4), 22-38. 
Makhbul, Z. M., \& Khairuddin, S. M. H. S. (2013). Stress among Malaysian academics: A conceptual study. International Journal of Academic Research in Business and Social Sciences, 3(1), 196.

Mérida-López, S., \& Extremera, N. (2017). Emotional intelligence and teacher burnout: A systematic review. International Journal of Educational Research, 85, 121-130. https://doi.org/10.1016/j.ijer.2017.07.006

Meyer, S.-C., \& Hünefeld, L. (2018). Challenging cognitive demands at work, related working conditions, and employee well-being. International journal of environmental research public health, 15(12), 2911. https://doi.org/10.3390/ijerph15122911

Ministry of Higher Education (2009). The Malaysian Higher Education System - An Overview.

https://www.studymalaysia.com/international/the-national-education-system / the-malaysian-higher-education-system-an-overview

Muchinsky, P. M. (2006). Psychology applied to work: An introduction to industrial and organizational psychology. Cengage Learning. https:// psycnet.apa.org/record/2001-06886-000

Mustapha, N. (2013). Measuring job satisfaction from the perspective of interpersonal relationship and faculty workload among academic staff at public universities in Kelantan, Malaysia. International Journal of Business and Social Science, 4(15), 120-124.

Nahrgang, J. D., Morgeson, F. P., \& Hofmann, D. A. (2011). Safety at work: A meta-analytic investigation of the link between job demands, job resources, burnout, engagement, and safety outcomes. Journal of Applied Psychology, 96(1), 71. https://doi.org/10.1037/a0021484

Omar, M. (2018). Occupational stress and its associated factors among academician in northern Malaysian universities. http:/ / repo.uum.edu.my/24709/

Pejtersen, J. H., Kristensen, T. S., Borg, V., \& Bjorner, J. B. (2010). The second version of the Copenhagen Psychosocial Questionnaire. Scandinavian Journal of Public Health, 38(3_suppl), 8-24. https://doi.org/10.1177/1403494809349858

Petitta, L., \& Vecchione, M. (2011). Job burnout, absenteeism, and extra role behaviors. Journal of Workplace Behavioral Health, 26(2), 97-121. https://doi.org/10.1080/15555240.2011.573752

Prieto, L. L., Soria, M. S., Martínez, I. M., \& Schaufeli, W. (2008). Una ampliación del modelo demandas-recursos laborales en la predicción del burnout y del engagement en profesores. [Extension of the job demands-resources model in the prediction of burnout and engagement among teachers over time.]. Psicothema, 20(3), 354-360. https:// psycnet.apa.org/record/2008-10293-003

Qamar, K., Khan, M. G. S. A., Khan, S. A., \& Tasawar, A. (2019). Educational and academic leadership. The Professional Medical Journal, 26(05), 769-775. https://doi.org/10.29309/TPMJ/2019.26.05.3475

Rahman, R. A., Mustaffa, W. S. W., Wahid, H. A., \& Yunus, N. K. Y. (2019). Exploring the factors affecting quality of work life among millennial academic staff in Malaysian public universities. International Journal of Asian Social Science, 9(6), 379-389. http://www.aessweb.com/html/4606

Rathmell, W. K., Brown, N. J., \& Kilburg, R. R. (2019). Transformation to academic leadership: The role of mentorship and executive coaching. Consulting Psychology Journal: Practice and Research, 71(3), 141. http://dx.doi.org/10.1037/cpb0000124

Raziq, M. M., Borini, F. M., Malik, O. F., Ahmad, M., \& Shabaz, M. (2018). Leadership styles, goal clarity, and project success. Leadership \& Organization Development Journal, 39(2), 309-323. https://doi.org/10.1108/LODJ-07-2017-0212 
Saleem, Z., Batool, S., \& Khattak, S. R. (2017). Relationship between leadership styles and organizational commitment: Moderating role of emotional intelligence and organizational support. Journal of Managerial Sciences, 11(1). https://www.qurtuba.edu.pk/jms/default_files/JMS/11_1/JMS_January_June 2017_71-84.pdf

Sinniah, S., Makhbul, M., Khan, Z., Perumal, G., Mohamed, H., \& Moona, R. K. (2018). Career motivation among lecturers' working at private universities in Malaysia. International Journal of Business \& Management Science, 8(2).

Schaufeli, W. B., \& Bakker, A. B. (2004). Job demands, job resources, and their relationship with burnout and engagement: A multi-sample study. Journal of Organizational Behaviour, 25, 293-315. https://doi.org/10.1002/job.248

Spector, P. E. (2019). Do Not Cross Me: Optimizing the Use of Cross-Sectional Designs. Journal of Business and Psychology, 34(2), 125-137. https://doi.org/10.1007/s10869-018-09613-8

Sung, T. P., Yee, G. C. S., Bahron, A., \& Rahim, I. H. A. (2017). The influence of training, employee engagement and performance appraisal on turnover intention among lecturers in Sabah private higher education institutions. Journal of Global Business $\begin{array}{llll}\text { and Social } & \text { Entrepreneurship, }\end{array}$ http://gbse.com.my/v1no3jan17/Paper-48-.pdf

Tseng, W. T., Dörnyei, Z., \& Schmitt, N. (2006). A new approach to assessing strategic learning: The case of self-regulation in vocabulary acquisition. Applied linguistics, 27(1), 78-102. https://doi.org/10.1093/applin/ami046

Watts, J., \& Robertson, N. (2011). Burnout in university teaching staff: A systematic literature review. Educational Research, 53(1), 33-50. https:// doi.org/10.1080/00131881.2011.552235

Williams, L. J., \& Anderson, S. E. (1991). Job satisfaction and organizational commitment as predictors of organizational citizenship and in-role behaviors. Journal of Management, 17(3), 601-617. https:// doi.org/10.1177/014920639101700305

Winefield, A. H., Gillespie, N., Stough, C., Dua, J., Hapuarachchi, J., \& Boyd, C. (2003). Occupational stress in Australian university staff: Results from a national survey. International Journal of Stress Management, 10(1), 51. https:// psycnet.apa.org/buy/2003-06067-006

Yavas, U., Babakus, E., \& Karatepe, O. M. (2013). Does hope moderate the impact of job burnout on frontline bank employees' in-role and extra-role performances? International Journal of Bank Marketing. https://doi.org/10.1108/02652321311292056

Yousefi, M., \& Abdullah, A. G. K. (2019). The impact of organizational stressors on job performance among academic staff. International Journal of Instruction, 12(3), 561-576. https:/ / eric.ed.gov/?id=EJ1220197

Yukl, G., \& Lepsinger, R. (2006). Leading change: Adapting and innovating in an uncertain world. Leadership in Action: A Publication of the Center for Creative Leadership and Jossey - Bass, 26(2), 3-7. https://doi.org/10.1002/lia.1154

Zarb, N. (2016). Stories from the middle: Perceptions of the roles of curriculum development managers in a Maltese further education organization. Journal of Advanced Research in Social Sciences and Humanities, 1(1), 18-29. https://dx.doi.org/10.26500/JARSSH-01-2016-0103

Zysberg, L., Orenshtein, C., Gimmon, E., \& Robinson, R. (2017). Emotional intelligence, personality, stress, and burnout among educators. International Journal of Stress Management, 24(S1), 122. https://doi.org/10.1037/str0000028 


\section{Appendix}

Variables Measurements

Keywords:

$\mathrm{BO}=$ Burnout

IDW= Physical demands

IDC $=$ Cognitive demands

IDE $=$ Emotional demands

IN-P= In-role performance

OCB-O= Extra-role performance (organizational citizenship behavior toward organization)

OCB-I= Extra-role performance (organizational citizenship behavior toward individual)

\begin{tabular}{|c|c|c|c|c|c|c|c|}
\hline Code & NO & Items & Never & Seldom & Sometimes & Often & Always \\
\hline BO1 & 10 & $\begin{array}{l}\text { How often have you felt } \\
\text { worn out? }\end{array}$ & 1 & 2 & 3 & 4 & 5 \\
\hline $\mathrm{BO} 2$ & 11 & $\begin{array}{l}\text { How often have you been } \\
\text { physically exhausted? }\end{array}$ & 1 & 2 & 3 & 4 & 5 \\
\hline $\mathrm{BO} 3$ & 12 & $\begin{array}{l}\text { How often have you been } \\
\text { emotionally exhausted? }\end{array}$ & 1 & 2 & 3 & 4 & 5 \\
\hline $\mathrm{BO} 4$ & 13 & $\begin{array}{l}\text { How often have you felt } \\
\text { tired? }\end{array}$ & 1 & 2 & 3 & 4 & 5 \\
\hline $\mathrm{BO} 5$ & 14 & $\begin{array}{l}\text { How often do you think: "I } \\
\text { can't take it anymore"? }\end{array}$ & 1 & 2 & 3 & 4 & 5 \\
\hline BO6 & 15 & $\begin{array}{l}\text { How often do you } \\
\text { susceptible to illness? }\end{array}$ & 1 & 2 & 3 & 4 & 5 \\
\hline IDW1 & 16 & $\begin{array}{l}\text { My workload is unevenly } \\
\text { distributed so it piles up. }\end{array}$ & 1 & 2 & 3 & 4 & 5 \\
\hline IDW2 & 17 & $\begin{array}{l}\text { I don't have time to } \\
\text { complete all my work } \\
\text { tasks. }\end{array}$ & 1 & 2 & 3 & 4 & 5 \\
\hline IDW3 & 18 & $\begin{array}{l}\text { I do get behind with my } \\
\text { work schedule. }\end{array}$ & 1 & 2 & 3 & 4 & 5 \\
\hline IDW4 & 19 & $\begin{array}{l}\text { I have enough time for my } \\
\text { work tasks (rs). }\end{array}$ & 1 & 2 & 3 & 4 & 5 \\
\hline IDC1 & 20 & $\begin{array}{l}\text { I have to keep my eyes on } \\
\text { lots of things during my } \\
\text { work. }\end{array}$ & 1 & 2 & 3 & 4 & 5 \\
\hline IDC2 & 21 & $\begin{array}{l}\text { My tasks need to remember } \\
\text { a lot of things. }\end{array}$ & 1 & 2 & 3 & 4 & 5 \\
\hline IDC3 & 22 & $\begin{array}{l}\text { My work demands that I } \\
\text { am improving at coming } \\
\text { up with new ideas. }\end{array}$ & 1 & 2 & 3 & 4 & 5 \\
\hline IDC4 & 23 & $\begin{array}{l}\text { My work requires me to } \\
\text { make difficult decisions. }\end{array}$ & 1 & 2 & 3 & 4 & 5 \\
\hline IDE1 & 24 & $\begin{array}{l}\text { My work puts me in } \\
\text { emotionally } \\
\text { situations. }\end{array}$ & 1 & 2 & 3 & 4 & 5 \\
\hline IDE2 & 25 & $\begin{array}{l}\text { I have to relate to other } \\
\text { people's problems as part } \\
\text { of my work. }\end{array}$ & 1 & 2 & 3 & 4 & 5 \\
\hline IDE3 & 26 & $\begin{array}{l}\text { My task is emotionally } \\
\text { demanding. }\end{array}$ & 1 & 2 & 3 & 4 & 5 \\
\hline IDE4 & 27 & $\begin{array}{l}\text { I get emotionally involved } \\
\text { in my work. }\end{array}$ & 1 & 2 & 3 & 4 & 5 \\
\hline
\end{tabular}




\begin{tabular}{|c|c|c|c|c|c|c|c|}
\hline Code & NO & Items & $\begin{array}{l}\text { Strongly } \\
\text { disagree }\end{array}$ & Disagree & Neutral & Agree & $\begin{array}{c}\text { Strongly } \\
\text { agree }\end{array}$ \\
\hline IN-P1 & 40 & $\begin{array}{l}\text { I fulfill all the responsibilities } \\
\text { specified in my job } \\
\text { description. }\end{array}$ & 1 & 2 & 3 & 4 & 5 \\
\hline IN-P2 & 41 & $\begin{array}{l}\text { I meet the formal performance } \\
\text { requirements of my job. }\end{array}$ & 1 & 2 & 3 & 4 & 5 \\
\hline IN-P3 & 42 & $\begin{array}{l}\text { I conscientiously perform } \\
\text { tasks that are expected of me. }\end{array}$ & 1 & 2 & 3 & 4 & 5 \\
\hline IN-P4 & 43 & $\begin{array}{l}\text { I adequately complete all of } \\
\text { my assigned duties. }\end{array}$ & 1 & 2 & 3 & 4 & 5 \\
\hline IN-P5 & 44 & $\begin{array}{l}\text { I sometimes fail to perform } \\
\text { essential duties of my job (rs). }\end{array}$ & 1 & 2 & 3 & 4 & 5 \\
\hline IN-P6 & 45 & $\begin{array}{l}\text { I sometimes neglect aspects of } \\
\text { the job that I am obligated to } \\
\text { perform }(\mathrm{rs}) \text {. }\end{array}$ & 1 & 2 & 3 & 4 & 5 \\
\hline OCB-O1 & 46 & $\begin{array}{l}\text { I sometimes take undeserved } \\
\text { work breaks (rs). }\end{array}$ & 1 & 2 & 3 & 4 & 5 \\
\hline OCB-O2 & 47 & $\begin{array}{l}\text { I adhere to informal } \\
\text { organizational rules devised } \\
\text { to maintain order. }\end{array}$ & 1 & 2 & 3 & 4 & 5 \\
\hline OCB-O3 & 48 & $\begin{array}{l}\text { I always give advance notice } \\
\text { when I am unable to come to } \\
\text { work. }\end{array}$ & 1 & 2 & 3 & 4 & 5 \\
\hline OCB-O4 & 49 & $\begin{array}{l}\text { I sometimes spend a lot of } \\
\text { time on personal phone } \\
\text { conversations (rs). }\end{array}$ & 1 & 2 & 3 & 4 & 5 \\
\hline OCB-O5 & 50 & $\begin{array}{l}\text { My attendance at work is } \\
\text { above the norm. }\end{array}$ & 1 & 2 & 3 & 4 & 5 \\
\hline OCB-O6 & 51 & $\begin{array}{l}\text { I sometimes complain about } \\
\text { minor things at work (rs). }\end{array}$ & 1 & 2 & 3 & 4 & 5 \\
\hline OCB-I1 & 52 & $\begin{array}{l}\text { I generally help others who } \\
\text { have been absent. }\end{array}$ & 1 & 2 & 3 & 4 & 5 \\
\hline OCB-I2 & 53 & $\begin{array}{l}\text { I take a personal interest in the } \\
\text { well-being of other } \\
\text { employees. }\end{array}$ & 1 & 2 & 3 & 4 & 5 \\
\hline OCB-I3 & 54 & $\begin{array}{l}\text { I generally help others who } \\
\text { have heavy workloads. }\end{array}$ & 1 & 2 & 3 & 4 & 5 \\
\hline OCB-I4 & 55 & $\begin{array}{l}\text { I go out of the way to help } \\
\text { new employees. }\end{array}$ & 1 & 2 & 3 & 4 & 5 \\
\hline OCB-I5 & 56 & $\begin{array}{l}\text { I generally take time to listen } \\
\text { to co-workers' problems. }\end{array}$ & 1 & 2 & 3 & 4 & 5 \\
\hline OCB-I6 & 57 & $\begin{array}{l}\text { I pass along work-related } \\
\text { information to co-workers. }\end{array}$ & 1 & 2 & 3 & 4 & 5 \\
\hline
\end{tabular}

